Article

\title{
Suffering the Sons of Eve: Animal Ethics in al-Ma arri's Epistle of the Horse and the Mule
}

\author{
Kevin Blankinship
}

Department of Asian and Near Eastern Languages, Brigham Young University, Provo, UT 84602, USA;

kevin_blankinship@byu.edu

Received: 1 June 2020; Accepted: 4 August 2020; Published: 10 August 2020

\begin{abstract}
In the year 1021 CE, blind author and skeptic Abū l-Alā' al-Ma'arrī (d. $1057 \mathrm{CE})$ wrote Risālat al-sāhil wa-l-shāhij (The Epistle of the Horse and the Mule), a winding prose work populated by animal characters who talk about poetry, grammar, riddles, and Syrian society on the eve of the crusades. Traditionally forgotten as a source for al-Ma'arri's pacifism, and his vegan worldview, the Șāhil lets readers see his thinking on animals more than most other works. After a brief survey of animals in Islam, which shows a mainstream desire for balance between human and non-human needs, as well as exceptional cases that strongly uphold animals as subjects per se and which stand as key inter-texts for al-Ma'arrī, this paper considers how the Sāhil champions non-human creatures through images of animal cruelty deployed to shock readers into compassion, and through poetry and popular sayings (amthāl) recast in a zoocentric mold. It, therefore, advocates with more fervor than anthropocentric Islamic writings on animals, such as Kalīlah wa-Dimnah or the letters of the Ikhwān al-Ṣafā'. However, this happens in a way that makes it hard to pin down the sources of al-Ma'arrī's thought. Furthermore, al-Ma arrī seems to contradict himself when, for example, he employs literal meaning when it comes to animal justice, even as he avoids literalism in other contexts. This calls his concern for animals into question in one sense, but in another, it affirms such concern insofar as his self-contradictions show an active mind working through animal ethics in real time.
\end{abstract}

Keywords: amthāl; Arabic literature; Islam; poetry; ethics; animals; veganism

\section{Introduction}

"We are the tribes of equus-hardships are thrown on our necks and attacks heaped on our backs." So whimpers the horse to the mule in the Risālat al-șāhil wa-l-shāhij (Epistle of the Horse and the Mule) of blind poet, philologist, and skeptic Abū l-'Alā' al-Ma arrī (d. 1057 CE). ${ }^{1}$ Writing around the year 1021 CE (Smoor 1982, p. 50), al-Ma arrī meant the Șāhil ostensibly as a plea to the Fatimid-vassal governor of Aleppo, Abū Shujā' Fātik 'Azīz al-Dawlah (d. 1022 CE) ${ }^{2}$, to pardon a land tax owed by al-Ma'arrī's relatives. This real life impetus mirrors the epistle's narrative frame, in which a cast of distressed animals-the titular mule (al-shāhij, "Brayer") and horse (al-șāhil, "Neigher"), as well as the dove (al-fākhitah, "Cooer"), the camel (Abū Ayyūb), the hyena (Umm 'Amr), and the fox (Thu'ālah)—try and fail to deliver a message to the governor. In the process, they swap rumors about contemporary Syrian society on the eve of the crusades, but in fact, the bulk of the work is a paean to language itself: Qurān, hadīth, poetry, grammar, popular sayings, riddles, and other genres.

Surviving in two manuscripts at the Hasaniyyah Archive in Rabat, Morocco, the Saahil was edited and published in 1975 by 'Âishah 'Abd al-Rahmmān "Bint al-Shātị" (daughter of the riverbank),

1 (Al-Ma' arrī 1975). For more on al-Ma' arrī's life and works, see Pieter Smoor, “Al-Ma' arrī,” EI2; (Antoon 2011).

2 Given this governor's death date, Pieter Smoor estimates that the Șāhil was completed no later than 1020 CE ("Al-Ma' arrī," EI2). 
whose critical introduction joins a mere handful of secondary studies (see also Smoor 1981, 1982; Barkoudah-Raoux 2009; Blankinship 2019a, pp. 15-18). Given this state of the art, people have often discounted the Șāhil as a window onto al-Ma'arrī's vegan ${ }^{3}$, pacifist worldview. This paper corrects the oversight with a study of animal ethics in the Șāhil, such as they are. Moving from the general to the specific, the paper starts by surveying early Islamic thought, in order to situate al-Ma arrī, who left behind few unambiguous statements about what he believed and why, in the context of other thinkers and texts. The first part of this survey establishes the mainstream tendency of Islam, which is to balance compassion for animals against human need for them as a life-giving resource. The second half of the survey considers cases that stand out from this norm, including Sufi animism and Turco-Persian reincarnationism, in giving greater priority to animals as moral exemplars or as subjects deserving justice in their own right. These cases represent key antecedents and inter-texts for understanding al-Ma'arrī.

There follows a sketch of animals as portrayed throughout al-Ma'arrī's texts. He is in many ways a more convinced animal ethicist, and a more zoocentric writer overall, than those, such as the Ikhwān al-Ṣafā', who uses animals mainly to comment on human society. That said, the finer points of his thought make it hard to pin down where he got his inspiration; he explicitly rejects Indic doctrines of reincarnation, and his focus on animal life per se departs from Byzantine neo-Manichaean groups, especially the Bogomils, whose avoidance of animal products draws on the (fundamentally anthropocentric) dualist struggle between spirit and matter. Such a challenge in establishing textual sources for al-Ma'arrī raises the possibility that more ephemeral matters, such as biography or psychology, played a role here. ${ }^{4}$ The paper's last two sections each inspect a rhetorical tactic of the Ṣāhil itself. The first is a grim parade of human cruelties as recorded in poetry, popular maxims (amthāl), and folklore, in order to shock readers into sympathy for nonhuman creatures. The second is a recasting of poetry and popular amthāl in a zoocentric mold, one that stands at odds with traditional interpretation. These two strategies affirm al-Ma'arrî's concern for animals, yet at the same time, they raise puzzling incongruities about intellectual and cultural history that are hard to answer for certain. The point is not to solve such questions, but instead to show al-Ma arrī working out his animal ethics-contradictions and all-in real time.

\section{Considering the Nonhuman in Early Islam}

To build his brick house of animal ethics, the Islamic thought tradition gave al-Ma arrī plenty of straw. The main current of that tradition tries to balance between nonhuman creatures as sacred, respect worthy creatures, and as useful resources for humans, who often take priority. This balance is struck elegantly and succinctly in two Qurānic verses about bees (16/al-Nahll: 68-69):

And thy Lord revealed unto the bees, saying: 'Take unto yourselves of the mountains, houses, and of the trees, and of what they are building. Then eat all manner of fruit and follow the ways of your Lord easy to go upon.' Then comes there forth out of their bellies a drink of diverse hues wherein is healing for men. Surely in that is a sign for a people who reflect. ${ }^{5}$

God esteems the insects by addressing them in their own right, yet simultaneously consecrates their "diversely hued" output (mukhtalifun alwānuhu)—honey—for human benefit. This counterpoise obtains in the hadith corpus too, wherein people are allowed to use animals, but within strict guidelines; they must provide for them, show kindness and relieve their suffering, and avoid their abuse. ${ }^{6}$

3 An admittedly anachronistic term, "vegan" comes closest to describing al-Ma'arrī's avoidance of all animal products, including fish, milk, eggs, and honey, plus his exhortation that everyone else should avoid them, too. For further discussion, see (Blankinship 2019b, p. 261), footnote 1.

4 Thanks to one of the anonymous reviewers for suggesting further discussion of this point.

5 (Arberry 1955), vol. 2, pp. 293-94.

6 For an overview of hadith that spell out these guidelines, see (Furber 2015, pp. 7-17). One sees an overall concern for animal welfare in hadiths that tell of the Prophet praising a man for giving water to a thirsty dog (the matn states, "There is a reward 
Metaphysically, the hadīth tradition but above all the Qurān honors animals as one of a few communities, alongside humans, angels, and jinn, who owe their existence to God and receive His mercy. Hence, Sarra Tlili's claim that the Qurān is basically theocentric and not anthropocentric-“any being that worships and obeys God obtains God's pleasure and is rewarded in the hereafter" (Tlili 2012, p. ix). Animals belong to God, a beneficent sovereign who cherishes them as valuable creations, and therefore how humans treat them can tip the scales of final judgement. ${ }^{7}$ Moreover, mainstream Muslim belief holds that, like humans, animals will resurrect physically after death (ibid., p. 10).

For jurists, theologians, and philosophers, these factors all point to justice: do nonhumans deserve it, and if so, to what extent and on what grounds? The Muslim tradition, while typically prioritizing human need, does show compassion to animals because they have the ability suffer, which in turn suggests the ability to feel and perceive, similar to humans in kind if not degree. Early Arabic lexicography, kalām, fiqh, and Qurānic tafsīr all classify a given animal as dhū rūh, literally "who has blown breath" but roughly "life force" or "soul," a concept which in early texts had a wider semantic range, but which becomes more closely linked to humans after the nineteenth century (Tlili 2017, pp. 18-21). In The Healing (Al-Shifā') and Salvation (Al-Najāh), Avicenna concedes to both humans and nonhumans a faculty called wahm, "estimation," which occupies a place "as the highest power among the soul's animal faculties" and can be thought of as a "pre-intellectual grasp of non-sensible intentions at the core of the judgements in question" - his favorite example is that of sheep sensing hostility from a wolf (Black 1993, p. 220).

Animals also enjoy powers of perception in the "Case of the Animals versus Man Before the King of the Jinn," which takes up most of Epistle 22 of the Brethren of Purity (Ikhwān 1957, vol. 2, pp. 203-377, at 213; Goodman and McGregor 2009, pp. 113-14). The segment about "The Acute Senses of the Animals" (Fī bayān jawdat al-ḥawāss fĩ l-ḥayawānāt) speaks of horses hearing footsteps in the night, or of ewes locating their farflung lambs one by one. Nonhuman characters also play a role in another philosophical allegory, Ibn Ṭufayl's Hayy ibn Yaqzān, whose title character is raised by a compassionate gazelle. After reflecting further, Hayy turns to vegetarianism to avoid "opposition to the work of the Creator," insofar as that work is embodied by His creatures (Ibn Tifayl 2008, pp. 77-79; Tufayl 2009, pp. 144-45).

With few exceptions, Islamic legal texts group animals under property ownership as far as their treatment goes (Furber 2015, pp. 1-2). In the Sunnī tradition, Hanbalī and Shāfi'i jurists list fewer human needs that justify violence to animals, than do the Hanafīs and Mālikīs. ${ }^{8}$ No wonder, then, that one of the firmest statements about "animal rights upon humans" (huqūq al-bahāim wa-l-hayawān 'alā al-insān) appears in an influential text of Shāfi ism, Rules for Deriving Laws for the Benefit of Living Things (Qawāiid al-aḥkām fī mașāliḥ al-anām ${ }^{9}$ ) by 'Izz al-Dīn ibn 'Abd al-Salām al-Sulamīîn (d. 1262 CE) (Al-Sulamī 1991). A manual of legal theory (uṣul al-fiqh) rather than practical rulings

for every moistened liver" [fì kulli kabidin ratbatin ajrun], meaning that every good deed, such as wetting the liver of thirsty animals-giving them water to drink-will be rewarded) (Al-Nīsābūrī 1991, vol. 4, p. 1761, \#2244; Al-Bukhārī 2002, p. 569, \#2363); or of a woman damned to hellfire for starving a cat to death (hattā māta jǘtan) (Al-Nīsābūrī 1991, vol. 4, p. 1760, \#2242-2243; Al-Bukhārī 2002, p. 569, \#2364-2365; p. 862 \#3482).

7 In the immediate Arab cultural milieu, some also saw kindness to animals as part of "manly virtue," murüah. For instance, the early writer Ṣālih ibn Janāh (d. ca. 767 CE) says in his Risālah fī l-adab wa-l-murüah: "A man's kindness to his riding animals, his taking good care of them, and his support for them, is indeed a righteous act, a way toward prosperity, and one

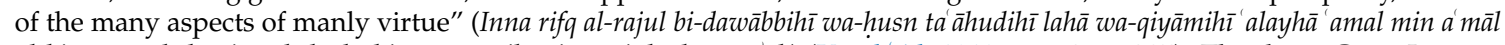
al-birr wa-sabab min asbāb al-ghinā wa-wajh min wujūh al-murüah) (Kurd 'Alī 1913, part 2, p. 305). Thanks to Geert Jan van Gelder for this reference.

8 According to Tlili, "the two [Sunnī] schools that are more text-oriented, the Shâfi $\overline{1}$ and the Hanbalī, are more attentive to nonhuman animals' well-being. Shāfi īs and Hanbalīs, therefore, can more accurately be described as Hadīth champions than as animal champions. The two descriptions, however, are not mutually exclusive" (Tlili 2015, p. 244).

9 Since the term anām refers, especially in post-Qurānic usage, to creatures seen as "rational" ('âqil)—namely humans, angels, and jinn (Tlili 2012, p. 139) - It makes sense that the Qaw $\vec{a}$ id should focus on human rather than animal welfare. That said, Qur'ānic usage is often more capacious, e.g., the word dābbah, which in later texts means "nonhuman animal" but which, according to Qurān commentators, includes humans too (Tlili 2010).

10 For more on this jurist, see (Sheibani 2020). 
(furū'), the Qawā'id is one of the first works to tackle the notion of "objectives" (maqāsid al-sharīah). It does this by indexing specific legal issues based on the welfare (mașlahah) versus the harm (mafsadah) done to God's creation.

In a section called "A Rule on Clarifying Sole Rights and Shared Rights" (Qāi idah fĩ bayān al-ḥuqūq al-ḳhāliṣah wa-l-murakabbah), Ibn 'Abd al-Salām has a short but remarkable passage about the claims that animals have upon humans (Al-Sulamī 1991, vol. 1, p. 167; Al-Sulamī 2010, Part 1, pp. 223-24). ${ }^{11}$ They include financial and other expenses to care for them, even after the animals have grown sick and give no benefit (bi-haythu lā yantafi u bihā). However, even as Ibn 'Abd al-Salām sympathizes with animals, he weighs their needs against those of humans, betraying a circumspection and "probabilism" typical of fiqh as a whole (Weiss 1998, p. xiii). In a longish section called, "On the Cases When Benefit is Found Together with Harm (Faṣl fī ijtimā' al-maṣāliḥ ma' al-mafāsid) (Al-Sulamī 1991, vol. 1, pp. 98-123; Al-Sulamī 2010, Part 1, pp. 130-55), he sizes up the relative merits and drawbacks in over 50 hypothetical situations, including several about animals (ibid. 1991, vol. 1, pp. 135-36, Numbers 10-12; ibid. 2010, Part 1, pp. 135-36). In Number 11, for example, he justifies eating "wild game" (al-sayd al-wahshī) without proper ritual slaughter (al-dhabh), a situation normally prohibited by Islamic law. However, Ibn 'Abd al-Salām allows for it if circumstances make performing the slaughter difficult, and if people would benefit from the physical nourishment (lākinnahu jāza bi-l-ḥaraj inda ta adhdhuri 1-dhabdh li-maṣlaḥat taghdhiyat al-ajsād).

While Ibn 'Abd al-Salām's brand of counterbalancing humans versus animals is dominant within classical Islam, some groups deviated from this norm in their strong support for nonhuman justice, often as a cosmic principle. It is worth considering these cases for a moment as meaningful precursors and inter-texts to al-Maarrī. One of the most obvious-and controversial—was the doctrine of metempsychosis, tanāsukh, sometimes called "projection," burūz, namely the movement of souls from humans into animals after death, which seems to rule out doing violence to animals on ethical grounds. Many observers associated this doctrine with extremist (ghulāh) Shi ites who rebelled against the early caliphs (Daniel Gimaret, "Tanāsukh," EI2), but it could have prevailed among the first Mu tazilīs, especially the disciples of Abū Ishāq Ibrāhīm al-Naẓāan (d. $835 \mathrm{CE}$ ). In the Kitāb al-ḥayawān (Book of the Living), al-Jāḥiz calls them aṣhāb al-jahālāt, "those who deal in absurdities," and credits them with panpsychism, i.e., the belief that everything possesses reason and, therefore, moral responsibility, even stones, mountains, flies, and lice; the aṣhāb al-jahālāt apparently went so far as to say that each of these communities had a prophet sent by God (Crone 2012a, pp. 34-39). ${ }^{12}$ Al-Jāhiz himself scoffs at the claim, evoking objections raised by Stoicism and other prior schools who denied the intrinsic moral value of animals on the grounds that they lack reason (Lagerlund 2018, p. 759). Whether his reports do justice to these beliefs in reality, they were taken up later by heresiographers like al-Shahrastāni (Walker 1991).

As an aside on al-Jāhiz, although he dismisses panpsychic beliefs as false, he does have a section in Kitāb al-ḥayawān called "Disputing the Slaughter and Killing of Animals" (hijāj fī dhabḥ al-ḥayawān wa-qatlihi) (Al-Jāhiz 1938, pp. 427-36). ${ }^{13}$ Addressed to a notional group of objectors who claim that Islam permits them to kill and eat animals, al-Jāhiiz offers a rebuttal based on the principle of mercy, which, as al-Jāhiz puts it, "Is all of a piece [al-raḥmah shakl wāhid]: whoever shows no mercy to the dog, also shows none to the gazelle; whoever shows none to the gazelle, shows none to the goat;

11 The passage on animals comes near the end of this section and the beginning of the next "On Classification of Rights into Unequal, Equal, and Disputed" (Faṣl fì inqisām al-ḥqqūq ilā al-mutafāwit wa-l-mutasāzwī wa-l-mukhtalaf fïhi) (Al-Sulamī 1991, vol. 1, p. 168; Al-Sulamī 1991, part 1, p. 225).

12 Al-Jāhiz ascribes a number of unorthodox opinions to these aṣhāb al-jahālāt, by whom he also meant the Jahmiyyah, that is, followers of slain theologian Jahm ibn Șafwān (d. 745 CE). He shows them, for instance, promoting extreme voluntarism, namely a denial of inherent differences between physical objects, since the only real difference lies in God's will. Supposedly the aṣhạ̄b al-jahālāt held to his view against al-Nazzām's doctrine of "latency," al-kumūn, which says that traits like wetness, dryness, heat, and saltiness inhere in the objects themselves. The logical conclusion of the Jahmiyyah viewpoint, at least as recounted by al-Jāhiz, is that, "apart from God, nothing really exists" (Crone 2012a, p. 29).

13 Thanks to Geert Jan van Gelder for this reference. 
whoever shows none to the sparrow, shows none to the human boy. Small and simple things lead to bigger ones [wa-șighār al-umūr tu'addī ilā kibārihā]" (ibid., p. 428).

Returning to the doctrine of metempsychosis, in the thirteenth and fourteenth centuries $\mathrm{CE}$, this doctrine found a beachhead within millenarian movements in the Islamic East. The Nuqtavīs or "Dottists" openly promoted a materialist-reincarnationist worldview (Amanat 1996; Babayan 2002, pp. 57-117), while the Mughal emperor Akbar the Great (d. 1605 CE) installed a cult that worshipped his person as divine and professed metempsychosis, and, by extension, vegetarianism (Moin 2012, pp. 130-69; Crone 2012b). Many occultist thinkers, physicians, and advisers to Persian-Turco-Mongol rulers believed in reincarnation but equivocated in public for fear of being tarnished as kuffār. Among their numbers were Sayyid Husayn Akhlātī (d. 1397 CE), the personal physician to Mamluk sultan al-Malik al-ẓāhir Barqūq (r. 1382-99 CE), and Akhlātị's disciples Ibn Turka (d. 1432 CE) and Badr al-Dīn of Simavna. While scholars once thought that the ideas of these men grew out of Jainism, emerging research shows that they were neo-Pythagoreans, especially since Pythagoras himself gave credit for his reincarnationist veganism to an ancient Persian sage: Zoroaster (Melvin-Koushki forthcoming, pp. 32-34). The problem of whether Hellenic or Indic currents supplied Islam with metempsychosis and related beliefs still breeds controversy (Crone 2012a, pp. 29-30).

To many thinkers, including al-Ma arrī, the movement of souls reeked of another strange doctrine: the equation of reality with divinity, dubbed "unity of being," wahdat al-wujūd, by Ibn 'Arabī's disciples (Ibn 'Arabī himself never used the term, calling it instead "real being," haqq al-wujūd) (Chittick 2020). Strict monotheists thought that this was too close to pantheism, and, therefore, polytheism (shirk), to pay it any heed, but it rang true for Sufi devotees. Of significance to animal ethics are the pietistic stories that show Muslim holy men communing with lions, dogs, fish, and, birds, since all of these creatures share in the divine essence. ${ }^{14}$

Many such stories are preserved in the Persian-language Tazkirat al-awliyā' (Memoir of the Saints) by poet and mystic Farīd al-Dīn 'Aț̣ār (d. $1221 \mathrm{CE}$ ). There, one reads about Khorasan-born jurist Sufyān al-Thawrī (d. $778 \mathrm{CE}$ ) and the "compassion that he had for all of God's creatures" (az shafaqat kih ū-rā būd bar khalq-i khudāy). In one anecdote, Sufyān frees a caged bird, which then visits him every night and eventually dashes itself to the ground following Sufyān's death and burial rather than live without him ('Atṭār 1905-1907, vol. 1, pp. 195-96; 'Aț̣ār 1966, pp. 169-70). Ibrāhīm al-Khawwāṣ (d. 903 CE), a figure known for advocating "self-abandonment" (tawakkul) (Leonard Lewisohn "Tawakkul," EI2), narrates in the first person about how he rescued a lion by healing its injured paw, after which the lion returned wagging its tail, bringing along its grateful cub (bachchah-i $\bar{u}$ ) and a round breadloaf (gardah) for the holy man ('Atțār 1905-1907, vol. 2, p. 149; Atțār 1966, pp. 169-70). Speaking of lions, legends about Sahl al-Tustari (d. $896 \mathrm{CE}$ ), recount that lions, dogs, and other wild beasts freely visited him, and that he would feed and take care of them. For this reason, according to 'Atțār, when a Sufi disciple once asked to come see him, he cautioned, "If you're afraid of lions, then don't spend time with me (agar tu az sibā' mī-tarsi bā man șuhbbat madār) ('Aț̣ār 1905-1907, vol. 1, p. 267; 'Aț̣āa 1966, p. 204). Such Franciscan tales tie together a strand running throughout philosophies like Sufi animism or Turco-Persian reincarnationism, namely that animals stand as moral exemplars. One sees al-Ma'arrī tugging at this thread to weave his own defense of animals.

\section{Animals in Al-Ma'arrī's Works}

Throughout his career, al-Ma'arrī looks to be a committed stalwart for animals. Many of the poems in his later collection Luzūm mā lā yalzam (Self-Imposed Necessity) plump for them unequivocally, though typically en route to condemning humans for cruelty or lack of scruple. On this idea, despite an outwardly greater focus on animals as subjects in their own right, he retains the anthropocentrism of

14 Written texts as well as visual artworks also show angels in animal form-lions, bulls, roosters, peacocks, and so on (Burge 2009, pp. 102-4; Gruber 2018, pp. 23, 128-30). 
texts that use animals to discuss good human society, like Kalilah wa-Dimnah, translated to Arabic by Ibn al-Muqaffa', or the Al-Namir wa-l-tha'lab (The Leopard and the Fox) of Sahl ibn Hārūn (d. 830 CE), director of the bayt al-hikmah and a staunch shu'übiyyah partisan, that is, a champion of non-Arabs and especially Persians in an Arab-dominant society. ${ }^{15}$ That al-Ma arrī uses animals to comment on humans brings up the question as to whether and how far one should take his interest in nonhumans at face value.

In one poetic couplet, for example, al-Ma arrī wants above all to prosecute his own kind as base and evil. To do this, he compares them unfavorably to wild birds, who do not indulge the same cruelties as people (meter: țawīl) (Al-Ma'arrī 1891-1895, vol. 2, p. 25; Atțār 1905-1907, p. 202 in English, p. 287 in Arabic):
Taṣaddaq 'alā l-țayri l-ghawādī bi-sharbatin/
mina l-māi wa-'dud'hā aḥaqqa mina l-insī
Fa-mā jinsuhā jānin 'alayka adhiyyatan/
bi-ḥālin idhā mā khifta min dhālika l-jinsī
Donate sips of water to birds, gone by morning,
and count them worthier of alms than men:
their kind commits you no harm at all,
even as you fear it from your own

Or in another poem, warning of death like so much of zuhd discourse, al-Ma' arrī says that it is only right for fate to be silent and callous-humans themselves cannot keep from being so reticent about their grisly treatment of animals (meter: khafīf) (Al-Ma'arrī 1891-1895, vol. 1, p. 58; Al-Batalyawsī 1991, p. 67):
Wa-wajadtu l-zamāna a'jama fažzan/
wa-jubārun fī ḥukmihā l-ajmāè
I found fate tongue-tied, bereft of mercy,
while the dumb beast's blood goes unavenged.

If a wrongfully wounded beast remains as jubār, "unavenged, unretaliated" (Lane 1984, vol. 1, p. $377)^{16}$ — a state of affairs for which humans are to blame, as al-Ma'arrī seems to imply-then it faces cruelty for no reason. Why, then, should humans expect such a reason when faced with their own looming, cruel demise? That they are found, in al-Ma'arrī's calculus, morally lacking compared to animals recalls Plutarch's imagined chat between Odysseus and Gryllus, one of the crewmen whom Circe changed into swine, and who, still in his porcine state, lists dozens of ways in which animals prove more virtuous than people - " "for without command or instruction, 'unsown and unploughed,' it were, [the souls of beasts] naturally bring forth and develop such virtue as is proper in each case" (Plutarch 1927-2004, vol. 12, pp. 501-31, at 501).

Other works by al-Ma arrī pose such troubling questions, or at least, they paint vividly colored tableaux from a nonhuman-and conspicuously pacifist and vegan-perspective. In the Risālat al-ghufrān, where al-Ma'arrī repeatedly lampoons overly literalistic visions of heaven-e.g., dajāj al-rahmah, "fat chickens of mercy," or farārīj al-khuld, "pullets of Eternity" (Al-Ma'arrī 2013-2014, vol. 1, pp. 206-7)—the narrative shows birds led to slaughter without pain, or gazelles hunted and killed without suffering. In fact, these creatures get replenished day after day so that their predators need not suffer privation, either (ibid., pp. 244-45).

15 (Sahl 1973). For more on his life and times, see Mohsen Zakeri, “Sahl ibn Hārūn,” EI2.

16 Lane quotes a saying of the Prophet, jurh al-ajmä jubārun, "The wound of the speechless beast is a thing for which no retaliation, nor expiatory mulct is extracted" (ibid.; Al-Bukhārī 2002, "Kitāb al-diyāt," p. 1709, \#6913; Al-Nīsābūrī 1991, vol. 3, "Kitāb al-hudūd," pp. 1334-35, \#1710; Al-Shāfi'ī 2001, vol. 10, "Bāb jurh al-'ajmā' jubārun," pp. 315-17) (thanks to Geert Jan van Gelder for the hadīth and al-Shāfi'ì references). This is almost certainly an unstated allusion of al-Ma' arrī's line. 
In the alleged Qurān parody Al-Fuṣūl wa-l-ghāyāt, at the start of the chapter rhyming in bā', for example, al-Ma arrī singles out proverbially industrious insects, like the common honeybee (al-jārisah, "buzzer") or the psyche moth bagworm (al-surfah, Psyche quadrangularis ${ }^{17}$ ), to show that the structures they build are worthier than human-made products like wine or weapons (Al-Ma'arrī 1938, pp. 39-40). In his chancery style guide Iṇkām șan'at al-kalām (Perfecting the Craft of Prose Speech), Andalusī vizier 'Abd al-Ghafūr al-Kalā'i (d. $1148 \mathrm{CE}$ ) quotes animal fables that he claims are salvaged from al-Ma'arrī's lost Kitāb al-qāif (Book of the Tracker). They include tales of a lion who turns to veganism, or of an ant brought close to death, and who, when its fellows fret for the sake of its soul, soothes them with talk of an eternal reward- "and this, since I never once spilled another's blood" (wa-dhālika annī lam asfik al-dam qațt) (Al-Kalāī 1985, pp. 204-6).

The closest thing to a Ma'arrian treatise on animal ethics are his exchange of letters with the Cairo-based Fatimid Shi'ite missionary al-Mu'ayyad fī l-Dīn al-Shīrāzī (d. 1078 CE) (Al-Ma arrī 1982, pp. 83-140; Margoliouth 1902). ${ }^{18}$ In what one could call a public relations maneuver-a learned debate put on display to garner intellectual and spiritual converts-al-Mu'ayyad asks al-Ma arrī to explain a poem in which the latter comes down against animal products of any kind, including fish, milk, and honey. ${ }^{19}$ The real question, however, is why al-Ma arrī went in for the vegan life at all, since, as reviewed in the first section, mainstream Islamic though allows people to eat meat. ${ }^{20}$

Al-Ma arrī's answer revolves around a hub of divine justice. Replying to al-Mu'ayyad's charge that anyone practicing veganism tries to outdo God in mercy, since Islam condones using animal products, he hints provocatively that the God of Islamic tradition is less merciful than reason suggests. "The prophets recall, peace be upon them, that The Creator-exalted be His strength-is gracious and merciful (raiuf rahīm)." ${ }^{21}$ However, we see evidence to the contrary: if He is merciful to the Sons of Adam, then He must also show mercy to other living beings (aṣnāf al-ḥayawān), which suffer pain in the slightest thing" (Al-Ma arrī 1982, pp. 109-12, at p. 110). However, God does let animals suffer, says al-Ma'arrī, as when a lion preys on weaker flesh, or when humans steal cow calves to eat them as veal. How can one therefore credit Him with mercy?

Lest al-Ma'arrī court charges of unbelief (kufr) or atheism (ilhạad) for calling God's pity into question, he defends vegan practice on agnostic grounds: the question of evil in this world is what poses the true mystery (sirr khafiyy), not God's compassion (ibid., p. 105). Lacking more certainty about where evil comes from, including the evil of animal cruelty, "those who profess religion have always been anxious to avoid meat, since it cannot be obtained without harm to a living creature" (wa-lam yazal man yantasibu ilā al-dīn yarghabu fī hijrān al-luhūm li-annahā lā yūṣalu ilayhā illā bi-l-īlām li-ḥayawān) (ibid., p. 107). By offering his zoocentric counsels, al-Ma'arrī departs from a more human-centered thinker like Abū Ḥāmid al-Ghazālī (d. 1111 CE), who writes of the purifying effects of hunger on the human soul—including heightened spiritual "insight" (bașīrah)—in the section "Kitāb kasr al-shahwatayn" (On Breaking the Two Desires, i.e., overeating and sexual desire) from Ihyā̄ 'ulūm al-dīn (Winter 1995, trans., pp. 117-32).

Where did al-Ma'arrī come by his beliefs? The question has bedeviled observers for centuries. Without evidence to the contrary, al-Ma'arrī's tendency toward compassion may have been a natural

17 Found in the grasslands and deserts of Central and Southwestern Asia, bagworms are known proverbially in Arabic for industriousness due to their oddly distinctive log cabin cocoon: așna min al-surfah (craftier than a bagworm). The cocoon is often made with twigs from the saxaul tree (al-rimth) and is known colloquially as mukhulat al-dhīb, "the wolf's antimony jar," since it appears in the branches of far-off trees, familiar only to wolves (Ibn Manzūur 1999, vol. 6, pp. 244-45).

18 For a fuller study of these letters with respect to veganism, see (Blankinship 2019b).

19 The complete poem can be found in Arabic at (Al-Ma'arrī 1891-1895, vol. 1, pp. 232-34); and in English at (Blankinship 2019b, pp. 284-87).

20 The Qurān endorses humankind's profiting from animals as a natural resource, whether of flesh and milk (e.g., 23/al-Mu'minūn: 21-2), wool, fur, and skin (e.g., 16/al-Nahl: 80), or prowess in hunting (e.g. 5/al-Māidah: 4).

21 This verbiage comes directly from the Qur'ān, e.g., Q 2/Al-Baqarah 143, inna llāha bi-l-nāsi la-ràüfun rahīmun ("Truly God is All-gentle with the people, All-compassionate," Arberry 1955, vol. 1, p. 46); Q 9/Al-Tawbah 128, bi-l-muiminina ra'üfun rahimun ("gentle to the unbelievers, compassionate," ibid., p. 223). 
one. Blind from childhood and having lost both parents before middle age, he seems deeply affected by life's tragedies, if his statements to al-Muayyad fì l-Dīn-made at the very end of al-Ma'arrî's life-describing physical and emotional suffering are any indicator. That believing Arab-Muslim authors in many eras faced their own hardships and still did not voluntarily avoid animal products reinforces the point. In addition, due to al-Ma'arrī's 18-month sojourn in Baghdad, many commentators single out Indo-Persian origins as an influence. However, this is less likely when one considers that al-Ma'arrī himself attacks Hindu beliefs-especially reincarnation, of which more below-in Risālat al-ghufrān, as well as what he sees as an abhorrent practice: satī or widow burning. ${ }^{22}$ As for pre-Islamic Persian creeds, in his first letter to al-Mu'ayyad, al-Ma'arrī explicitly mentions-and rebuffs-Manichaean dualism as the answer to the problem of evil and as grounds for vegetarianism, as did Augustine before him in The City of God (Al-Ma arrī 1982, p. 106; Augustine 1957, book 1, p. 20).

Another imaginable yet little discussed channel for vegetarian belief in medieval Islamdom was the Hellenic one. Al-Ma arrī lived at a time of religious ferment in Byzantium, less than a hundred miles to the northwest and which some biographers say he visited in his youth. ${ }^{23}$ Especially conspicuous in that realm was what Dmitri Obolensky called Balkan neo-Manichaeism, flourishing from the tenth to fifteenth centuries CE and whose forerunners had been hounded as heretics under Justinian II in the seventh (Obolensky 1948, p. 27). It spanned a number of groups, such as the Paulicians, the Massalians, and the Blakhernites, but above all the Bogomils, a dualist, vegetarian sect denounced by Cosmas the Priest in the tenth century CE (not to be confused with Cosmas I or II, both subsequent patriarchs of Constantinople) (ibid., p. 104). ${ }^{24}$

Some of this Manichaean tumult might have fueled al-Ma'arrī's thinking, but his distinctly zoocentric approach, fixated on sparing God's creatures from suffering, parts ways with the Byzantine dualists, who based their ideas on the permanent struggle between spirit and matter and the moral superiority of the former. Thus, even if Bogomilism fired up the engine of al-Ma'arrî's thought, he would have ultimately taken it down a different path. Still, it is clear enough that al-Ma'arrī knew of canonized Greek medical authorities like Galen, ${ }^{25}$ who had suggested restricting one's meat intake for better health (Al-Ma'arrī 1982, p. 111; Margoliouth 1902, p. 319).

Given the history of building vegetarian practices atop a reincarnationist groundwork, it seems crucial to ask: did al-Ma arrī think that human souls migrated after death? If so, then he convincingly hid any such views. ${ }^{26}$ In fact, judging by the poetry of Saqt al-zand, he knew about—and dismissed as false- the doctrine of metempsychosis from an early age, maybe even before his trip to Baghdad circa 1007 CE. In Qașīdah Number Five, following the chronology of Husayn et al., al-Ma' arrī answers a poem by a certain Shi ite notable (sharīf 'Alawī) called Abū Ibrāhīm Mūsā ibn Ishāạ. With memorable disdain, the line in question plays on this Abū Ibrāhīm's name in order to invalidate his belief in reincarnation (meter: wāfir) (Al-Ma'arrī 1945, vol. 1, p. 276, line \#51; Al-Jundī 1962-1964, vol. 3, p. 1337):

Wa-law ṣaḥha l-tanāsukhu kunta Mūsā/

wa-kāna abūka Isḥāqa 1-dhabīhāā

22 "Those who have witnessed Indians practice self-immolation (man shahida īhrāqahum nufüsahum) tell that when they feel the fire burning they want to get out, but those present push them back with sticks and sharpened swords. There is no god but God; << You have done a monstrous thing! >> [quoting Q 19/Maryam, v. 89]" (Al-Ma'arrī 2013-2014, vol. 2, pp. 80-83).

23 Ibn al-'Adīm writes that al-Ma' arrī went to Antioch (Husayn et al. 1944, pp. 555-56), while Jamāl al-Dīn al-Qifți says he visited Latakia (Al-Qifțī 1950, vol. 1, p. 49). Even though such details differ, the biographers who mention this episode all agree that al-Ma' arrī traveled beyond Greater Syria in his youth, and that the trip affected his worldview.

24 In the twelfth-century Byzantine historical epic The Alexiad, at the back half of Book 14 and the middle of Book 15, Princess Anna Komnene (d. 1153 CE) exposes various dualist offshoots for the perceived threat they posed. She calls the Bogomils "a serpent lurking in its hole" and describes how, like a viper, their ideas had slithered into small towns and villages, taking hold especially among the peasants (Komnene 1969, pp. 455-63).

25 For more on Galen as a canonical source of Byzantine medicine, see (Nutton 1984).

26 Muhammad Salīm al -Jundī rolls out statements by al-Ma arrī on a number of theological positions, especially those for which he was charged with unorthodox views. (Al-Jundī 1962-1964, vol. 3, pp. 1398-487). Even though al-Jundī seems eager to defend al-Ma arrī, he adds up enough evidence to show that al-Ma arrī was not a convinced reincarnationist. 
If the doctrine of reincarnation were right,

then you'd be Moses (Mūsā)

and your father Isaac (Isḥāq) the Slain!

Later in his career, al-Ma arrī still thought that certain Shiite groups- as well as Hindus and the followers of murdered Sufi al-Hallāj (d. 922 CE)—believed in metempsychosis. He writes in Risālat al-ghufrān that:

This sect [al-nihlah, referring to al-Hallāj and his disciples] propagates the idea of metempsychosis [al-tanāsukh], which is an ancient belief held by the Indians [ahl al-hind]. It has also become common among a group of Shilites [jamāah min al-shīah]. We ask God for success and protection (Al-Ma'arrī 2013-2014, pp. 78-79). ${ }^{27}$

That al-Maarrī puts reincarnation squarely in India belies sophisticated contemporary knowledge—above all by the Persian traveler and polymath Abū Rayhān al-Bīrūnī (d. 1050 CE)—of non-Indic and especially Hellenic writings on metempsychosis (Walker 1991, pp. 220-22). ${ }^{28}$ In addition, given the fact that al-Ma'arrī was regularly accused of heterodox belief in "Brahmanism" (al-barhamiyyah) for his vegan lifestyle ${ }^{29}$; and given the fact that he thought, as others did, that some Shi ites believed in reincarnation, it is remarkable that neither he nor al-Mu'ayyad fī l-Dīn al-Shīrāzī charged each other more vehemently with such beliefs.

One might think that by snubbing these different groups, al-Ma' arrī was just "writing between the lines," that is, concealing his unorthodox views for fear of being persecuted (Strauss 1941, p. 490). This possibility again brings up the question: how far should readers take his concern for animals at face value? However, most of the time, he is quite pleased to trumpet his thoughts, plus the fact that his disdain for Sufis, Hindus, and extremist Shi ites stays consistent throughout his writings. Short of equating literary discourse with reality, it is safe to assume that he in fact disavowed these ideas as he claims. In addition, as noted, the content itself-being the main way to know how he got his ideas, short of new evidence coming to light-is not enough to tell which sources inspired him. Several are possible, especially Balkan neo-Manichean groups like the Bogomils; Iranian breakaways from Zoroastrianism like the Khurramīs or neo-Mazdakīs (Babayan 2002, esp. pp. 137-54, 262-92); Indic religion as conveyed by medicine; or some blend of these. ${ }^{30}$ But the details of his thought depart enough from any single point of supply as to rule it out as the only one. The best one can do is to orient him to other thinkers and texts, as the preceding sketch tries to do.

Perhaps the weightier influences on his thinking are lost to history. Returning again to the trip to Baghdad or the childhood stay in Byzantine lands, it is unlikely that new evidence will emerge of conversations with travelers, chance encounters with eccentric folk beliefs, and so forth. Nor should one overstate claims about the past without a basis in historical data. However, to discount the possibility that undocumented conversations or encounters made their way into al-Ma arrī's worldview would mean over-textualizing a past that often evades written capture. ${ }^{31}$ As Thomas Glick says regarding Christian-Muslim cultural transfer on the Iberian peninsula, "of all the processes of acculturation, non-formal cultural diffusion is perhaps the most important" (Glick 1979, p. 152). Therefore, so too might al-Ma arrī have seen, heard, or read things for which no trace remains. Perhaps he did indeed absorb Indic or Hellenic injunctions against animal harm, or, on the other hand, perhaps he happened to meet a single individual with similar ethical concerns. Together with his apparently inborn awareness

27 As Kathryn Babayan points out, the Sufi belief in wahdat al-wujūd—which here al-Ma' arrī conflates with metempsychosis—was, at least in the mind of heresiographers, shared by Iranian neo-Pythagorian movements like the Nuqțavis.

28 Nor is this for al-Bīrūnī's lack of knowledge about the Indic tradition, reckoning by his commentary on yoga philosophical texts (Al-Bīrūnī 2020).

29 For examples of such accusations, see (Al-Jundī 1962-1964, vol. 1, pp. 406-9).

30 Recent research casts doubt on some of the stark lines that have been by scholars between Hellenic and Indian thought, judging from centuries of direct contact between the two (Stoneman 2020).

31 Many thanks to one of the anonymous reviewers for suggesting further discussion on this point. 
of nonhuman suffering and a strongly felt sense of justice, there are unlikelier explanations than these for how al-Ma arrī came by his convictions.

\section{Shocked to the Point of Compassion}

As stated, the action of the Șāhil—such as it is—unfolds as one animal after another passes by the waterwheel-bound mule (al-shāhij) and asks about its plight. The mule, in turn, falls on these passersby to carry a plea to the governor of Aleppo, 'Azīz al-Dawlah, since it suffers daily beatings at the hands of a "lazy day laborer" (ajīr kaslān) (Al-Ma arrī 1975, p. 98). This scenario already betrays a concern for animal welfare, although Pieter Smoor's judgment that the mule in fact represents al-Ma arrī suggests that readers should not draw neat correspondences, at least not in this section (Smoor 1981, pp. 57-61).

Instead, where one finds the thinnest veneer between literary discourse and what must be al-Ma'arrī's actual view is the first monologue of the horse, the titular șāhil, "neigher" (Al-Ma'arrī 1975, pp. 108-65). The mule begs it for help delivering a message to 'Azīz al-Dawlah by appealing to biological relations, calling the horse "brother of my mother" (yā khālī) (ibid., p. 96). This appeal by the horse rejects in typical Ma arrian fashion, that is, with a long list of homonyms or near homonyms-many of them animal names-that refer to different things despite sounding or looking the same, such as the clan of Dhib within the Azd tribe, versus the wolf (dhib) that "schemes evil plots" (yahtabilu bi-jaddin natịinin) (ibid., pp. 110-13, at p. 112). The point is that language can deceive, as when the mule calls the horse "uncle" despite there being no such relation, at least from the horse's perspective. "So don't let names dupe you," it chides the mule- "before someone observed the lightning, the sky was already there" (qabl al-shāim kānat al-samā) (ibid., p. 113).

Then the horse goes to work on the second part of the mule's plea: the fact that it wants help from a human, 'Azīz al-Dawlah. "Don't you know that the Sons of Adam are the sovereigns of the earth? [mulūk al-arḍ] ... As for us, we are the tribes of equus (ma'āshir al-jabhah). Hardships [ghamarāt] are thrown upon our necks and attacks [ghārāt] are put upon our backs" (ibid., p. 115). There ensues a litany of evils inflicted upon animals by humans, a litany which, despite the horse's aim of logically proving that humans are not trustworthy, is vivid and disturbing enough that the intended shock to readers becomes its own form of argument.

For instance, time and time again, the horse reminds the mule that domesticated animals form bonds with humans, only for the humans to betray those bonds and kill them. "What about cows that till the ground? [al-muthīrāt al-kawārib]" it asks rhetorically. "Humans use them, and then they eat them!" (ibid., p. 128). When a bull's flesh is sufficiently marbled with fat (lammā shurija lahm Abī l-Muzāhim bi-l-nayy ${ }^{32}$ ), it is taken to market and carved up, setting aside the erstwhile society between man and beast (ibid., p. 130). Ranchers give food to chickens not out of sympathy, but rather to dupe them into sticking their necks into a trap (al-sita) (ibid., pp. 128-29). However, this is not all, continues the horse: wild animals (al-wahsh al-bāhilah) suffer no less than do tame ones (al-bahāim al-ahliyyah). It recalls goats ascending up a mountain (al-aw'âl al-āqilah), whom hunters paralyze (fa-qa'adūhā) by shooting their haunches, then take them for food and leave their orphaned young (ghufr waqil) (ibid., p. 140). When wild jennies (al-ānāt) make a loud commotion (al-jarabbah), it is not enough scare off hunters from killing them (ibid., p. 134). Further, with ostriches, people will stab them and steal their eggs for food (ibid., p. 144), and so on with many different species, including rabbits, foxes, lizards, jerboas, bees, and even snakes and mice, which some sources say the Bedouin would eat (ibid. pp. 151-53).

32 The word for fat, nayy, "raw" or "untouched by fire," is originally written nay. Traditionally, desert Arabs distinguished fat as an uncooked substance from flesh, sometimes called nadīj, "cooked" (Lane 1984, vol. 2, supplement, p. 2930). Abu l-Muzāhim, or sometimes Ibn al-Muzāhim or simply muzāhim, "fighter," can by association mean a raging elephant or, in this context, a bull with broken horns (munkasir al-qarnayn, reading munkasir for munkar in the text) (Ibn Manzūr 1999, vol. 6, p. 29). 
Of the more ghoulish practices recalled by the horse, certain Bedouin tribes would supposedly waterlog their camels over ten days before a long desert journey, letting them fill their humps on the first day, then starving them of water for another eight days, and finally letting them drink again on the tenth day-as al-Ma' arrī says, z̧amma'ù al-ibl ishran ("they thirsted their camels for a ten-day period [eight days without water]"; Lane 1984, vol. 2, p. 2103). Then, when all the water had run out and circumstances in the barren wastes grew dire, they would rip open the camel's stomach and drink the excess water (baqarū buțūnahā fa-sharibū al-faẓ. $)^{33}$

In the voice of the horse, al-Ma arrī quotes several poets who allude to this practice, at least in the horse's (and probably al-Ma'arri's) estimation. For example, here is line 49 from a mufaddaliyyah in the basịt meter by 'Alqamah ibn 'Abadah "al-Fahl" (fl. mid-sixth cen. CE) (Al-Ḍabbī 1921, vol. 1, p. 818, poem \#120; vol. 2, p. 337):

Wa-qad uṣāḥibu aqwāman ța āmuhumū

khuḍru l-mazādi wa-laḥmun fīhi tanshīmū

And time was that I went around with a people ${ }^{34}$ whose diet

is the dark-hued water of provision bags, and rank, fetid meat.

Most commentators, ${ }^{35}$ including al-Anbārī (ibid.), understand the phrase khuḍru l-mazādī to mean either water pouches, normally made of goatskin, in which the water is covered by algae, or else stomachs (kurūsh) removed from animals and used as water bladders. Regarding the strange color, Ibn Manzūr explains that "the water has remained a long time in the waterskins and thus gone green/darkened ${ }^{36}$ with age" (inna l-mā' baqiyat fi l-adāwī fa-khḍarrat min al-qidam) (Ibn Manzūr 1999, vol. 14, p. 152). The stomachs may also contain meat, as Ibn Qutaybah says about the word tanshīm ("rotting," "putrefaction"): "Whenever the desert Arabs went military campaigns and crossed long distances, they would carve up meat and stow it in an animal's stomach [used as a provision bag]; and after many days, the meat would go bad, and this is [the meaning of] 'its rotting'" (kānū idhā ghazaw wa-sāfarū qața ū l-laḥm fa-ja'alūhu fī kirsh fa-idhā atā 'alayhi ayyām taghayyara fa-dhālika tanshīmuh) (Ibn Qutaybah 1953, vol., 3, pp. 381-82; Al-Bațalyawsī 2008, vol. 1, p. 387). However, the horse in al-Ma arri's story quotes 'Alqamah's line because it thinks—or it wants readers to think—-that it is about slaughtering camels in order to consume their stomach content. This demonstrates al-Ma'arri's method of creatively reinterpreting well-known passages to fit his pacifist, zoocentric message, although at least one commentator, al-Akhfash al-Aṣghar, does support al-Ma arrī's understanding of the line by 'Alqamah (Al-Akhfash 1999, p. 643). ${ }^{37}$ More on such interpretive somersaults by al-Ma'arrī in the next section.

33 In literature, disemboweling and the like seems emblematic of a particularly gruesome death. In his Brains Confounded by the

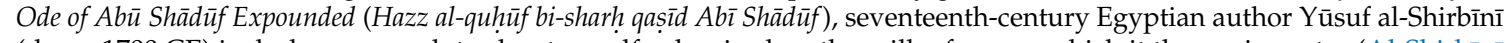
(d. ca. $1700 \mathrm{CE}$ ) includes an anecdote about a wolf cub raised on the milk of a ewe, which it then eviscerates (Al-Shirbinī 2016, vol. 1, pp. 40-41); and about a hyena raised by a Bedouin man, whose stomach the hyena later rips open (ibid.). Apart from highlighting the starkness of the violence, these stories are meant as evidence that humans, like animals, "will not escape their inborn nature" (lā yakhruju al-insān min tab ihi, ibid., pp. 38-39).

34 There is a variant reading of the first hemistich: Wa-qad uṣāhibu fityānan țá āmuhumu, "and time was that I went with young warriors [geared for raiding] whose food was" etc.

35 Many thanks to Geert Jan van Gelder for checking my understanding of this line, and for suggesting the various references that appear in this paragraph.

36 Khudr can mean green, but also brown or black in classical Arabic-presumably this refers to how the water was colored by the dark contents of their stomachs, but possibly also bile (this seems less likely).

37 "Whenever the desert Arabs rode through a barren wasteland, i.e. one without moisture, they would give water to a sturdy camel, then pierce its snout [to bind it] so that it could not chew its cud. Then, when thirst overtook them, they would puncture the camel's upper chest and drink whatever water was in its stomach. The name of that water is fazz, 'pressed-out'"

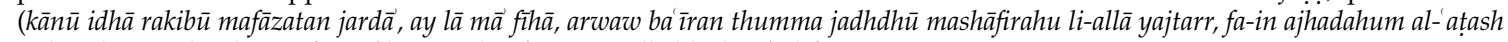
naharūhu wa-sharibū mā fì jawfih̄̄ min al-mä', wa-ism dhālika l-mä al-fazz). 
Going further, the horse character says that the Bedouin also used to open the veins of camels and drink their blood, ${ }^{38}$ and that for the truly destitute, dead camel carrion offered relief from hunger. Again, poetry serves as proof of such horrors, with anonymous lines quoted in rajaz meter and with a tinge of black humor (Al-Ma'arrī 1975, p. 125):

Inna l-saīida man yamūtu jamaluh yakulu lahman wa-yaqillu 'amaluh

Happy is he whose camel dies, so he eats the meat, saves himself the work! ${ }^{39}$

The horse goes on to describe how humans wear out their camels with overmuch walking, or how, as in a poem attributed-incorrectly ${ }^{40}$ — to Juwayriyah ibn Asmā' al-Fazārī, travelers slaughter their riding camels so that an attacking wolf will eat them instead of the humans (ibid., p. 126). With these examples at its command, the horse builds to a crescendo: "No animal has endured torture from the Sons of Eve like the camel has" (wa-mā ṣabara shay'un min al-bahāim 'alā 'anat Banī Ḥawwā' mā șabarathu al-ibil) (ibid., p. 125).

This gallery of crimes echoes an earlier text to which al-Ma arrī's Ṣāhil might owe a debt, however indirectly, in its display of human cruelty for the sake of persuading readers: The Case of the Animals versus Man Before the King of the Jinn, by the Brethren of Purity. Throughout the trial, the spokesman of the beasts (zaìm al-bahāim) is in fact a mule (baghl), making for a conspicuous link between this work and al-Ma'arrī's. ${ }^{41}$ The mule of the Brethren of Purity bemoans how humans have treated nonhumans from the earliest days (fì bad' al-khalq), driving them from their homes and enthralling them as beasts of burden (Ikhwān 1957, vol. 2, pp. 203-4; Goodman and McGregor 2009, pp. 99-100). Then, in the section "On the Animals' Complaint of Oppression by Humans" (Fī bayān shakāwat al-hayawān min jawr al-ins), readers find a long list of crimes that indict humans on their face.

"As for feeding and watering us," charges the mule in Goodman and McGregor's English, "these things are not done out of kindness or compassion, as he [the human spokesman] claims, but for fear lest we die and lest they lose their investment in us and the benefits they take from us" (bal makhāfatan an nahlika fa-yakhsarū athmānanā wa-tafūtahum al-manāfi minnā) (Ikhwān 1957, vol. 2, p. 215; Goodman and McGregor 2009, p. 116). Such alleged self-interest flouts the counsels of an author like Ibn 'Abd al-Salām to care for animals even when they give no direct benefit. Then, as if on cue, other animals take up the mule's mantle and chime in with their own objections. The ass (himār) complains of being overburdened with bricks; the ox (thawr) protests being chained to human waterwheels and

38 In his edition of Ibn al-Kalbī's Kitāb al-aṣnām (Book of Idols), Ahmmad Zakī Bāshā reproduces a marginal note from the unique Egyptian National Archives manuscript (Ibn al-Kalbī 1995, p. 3) explaining the phrase inna llăha arāhakum min al-sajjah wa-l-bajjah, "God has given you respite [i.e. freed you] from the pagan god Sajjah and the practice of blooddrinking." The note glosses al-sajjah as "an idol once worshipped alongside Allāh" (șanam kān yu'bad min dūn Alläh), and al-bajjah as "phlebotomized blood which the desert Arabs would consume in times of crisis" (al-fașìd alladhī kānat al-'arab ta'kulu fì l-azmah). In his Kitäb al-bukhalä (Book of Misers), al-Jāhiz mentions majdūh, a Bedouin "emergency dish" made of blood mixed with other things (Al-Jāhịiz 1948, pp. 216, 218; Al-Jāhị 1997, trans. Serjeant, pp. 195, 197; Ibn Durayd 1987-1988, vol. 1, p. 435). Thanks to Geert Jan van Gelder for the references in al-Jāhiz and Ibn Durayd. Setting aside the question of historicity, such references show that, in the Arab popular imagination, opening the veins of mounts and pack animals was considered a standard tactic of Bedouin desert survival.

39 Also appearing in the "Kitāb al-ța'ām" (Book of eats) of Ibn Qutaybah's 'Uyūn al-akhbār (Book of Choice Accounts) (Ibn Qutaybah 1996, vol. 3, p. 213).

40 There is a confusion, as noted in (Ullmann 1981, p. 88, note 84), with the well-known poet Asmā' ibn Khārijah al-Fazārī (on whom see e.g., Sezgin 1974-1995, vol. 2, p. 329); Bint al-Shātí', editor of the Șāhil, did not notice this. Perhaps al-Ma arrī misremembered; Ullmann thinks it is due to copyists. Ullmann gives all eighteen lines in transliteration, translation, and with extensive commentary (Ullmann 1981, pp. 87-96). The lines are from a poem by Asmā' ibn Khārijah (Aḥmad and Hārūn 1955, pp. 48-52). Many thanks to Geert Jan van Gelder for pointing out the misattribution and recommending these sources.

41 Other talking mules in Arabic literature include the donkey-shaped jinn that appear in the fourth and final section of Ibn Shuhayd al-Andalusī's Risālat al-Tawābi wa-l-zawābi' (The Treatise of following spirits and whirling demons) (Al-Andalusī 1967, "Hayawān al-jinn," pp. 147-52), and in the Thousand and One Nights (Mahdi 1984-1994), the deceitful donkey of "Hikāyat al-himār wa-l-thawr" (The Tale of the donkey and the ox) (Thousand and One Nights, Mahdi 1984-1994, vol. 1, pp. 66-69; Heller-Roazen 2010, pp. 13-15). 
millstones (dawālībihim wa-arhiyatihim); the ram (kabsh) resists having its kids stolen so that humans can eat them and steal their milk; the horse (faras) denounces being bridled and bitted; the rabbit (arnab) laments being hunted by dogs; and on and on. As in the Șāhil, such testimonies pile up with nearly physical force, pressing readers into the ironic position of siding with nonhumans against their own kind.

In the end, however, the pleas fall short of convincing the jinn king, who tosses out the animals' case. To account for the discrepancy between this result and the tale's overall egalitarian tenor, Tlili pits the Brethren's hierarchical worldview, which triumphs in the end, against an even-handed view of animals deriving from the Qurān (Tlili 2014). Of course, the result of the trial may be more complicated than this; the humans emerge victorious simply because a tiny number of them are saints, which leaves untouched the accusation that the vast majority of humans are worse than animals. ${ }^{42}$ Meanwhile, al-Ma'arrī himself sides with his own horse character's verdict, if one gauges from the short, token rebuttal offered by the mule. It spends barely two edited pages-in patent contrast to its conversation partner's lengthy descant—quashing the horse's claims and pointing out human charity (iḥsān) before moving to the issue of whether some lines of poetry count as rajaz or not (Al-Ma' arrī 1975, pp. 173-75). While no explicit position is advanced, if one reads between the lines, there are differences of length, detail, and enthusiasm between the horse's talk and that of the mule that serve to confirm al-Ma'arrī's support for nonhuman justice.

\section{From Poetic Myth to Zoocentric Reality}

As the foregoing shows, literary discourse gets pressed into the service of arguments pro and contra during the horse's monologue, as it does throughout Risālat al-Ṣāhil wa-l-shāhij. Although a tried and true rhetorical move in classical Arabic—one which would be familiar even in the hypothetical text world of the Șāhil, a text world for which one assumes a basis in culturally Islamicate discursive genres-using poetry and maxims (amthāl) for historical, sociocultural, or rhetorical evidence is something that the horse still feels it needs to justify. "All of this represents more than enough desert Arab poetry to establish proofs [of my point]," it says defensively (Al-Ma arrī 1975, pp. 134-35). "I only produce it here like a bearer of news showing you the sun [kamā yushīru al-muhaddith ilā Umm Shamlah ${ }^{43}$ ], or the night rider showing you the moon's halo" [wa-yurīka rākibu laylihi al-sāhirah]—in other words, to show the mule, plus any eavesdroppers, ${ }^{44}$ the source of its own ideas and the trajectory of its thought.

In particular, pre- and early Islamic hunting poetry enters the mix, especially Hudhalī verse, with its "depictions of animals, especially onagers and oryx, that are killed by hunters as representatives of the ineluctability of fate" (Miller 2016, p. 118). At one point, al-Ma'arri's horse brings out nine lines of a 44-line poem by Sāidah ibn Ju'ayyah, ${ }^{45}$ a mukhaḍram—a poet whose life spanned before and after the coming of Islam — who, along with his rāwī (transmitter and pupil) Abū Dhu'ayb Khuwaylid ibn Khālid (d. ca. 649 CE), also a mukhaḍram, form a distinctive school among the Hudhalīs; according to Nathaniel Miller, they share common characteristics "in the depictions of rain storms, honey-collectors, vocabulary and stylistic devices like repetition" (ibid., p. 312; see also pp. 377-79, 389-92).

42 Thanks to one of the anonymous reviewers for pointing this out.

43 Al-muhaddith normally carries the technical meaning of a hadith transmitter. So it may here too, although the full Arabic statement is general enough not to mark it either way. Umm Shamlah is a nickname for the sun; it can also mean wine or, more generally, the world and its fleeting joys, "so called because compassing [shamlah] the intellect of a man and concealing it" (Lane 1984, vol. 1, p. 1610).

44 In discourse analysis, sociologist Erving Goffman is credited with the distinction between "overhearers," i.e. those who are privy—or potentially privy—to a conversation not directly "intended" for them, and "ratified participants," namely those for whom a conversation is intended, whether or not they happen to be listening (Goffman 1981, pp. 124-59). Whatever one thinks about an author's ability to imagine future readers, if one assumes that there are readers whom the author has not thought of, but who may in fact one day read his works, then they could be described as overhearers.

45 For more on this poet, see (Al-Sukkarī 1965, vol. 3, pp. 1095-185). 
The lines in question-Numbers $8-16$, with variant readings and line ordering in al-Sukkarī's recension (Al-Ma'arrī 1975, pp. 142-43; Al-Sukkarī 1965, vol. 3, pp. 1122-38) ${ }^{46}$-imagine a hunter taking down a curvehorned ibex (dhū hayadin, or dhū hiyadin in al-Sukkarī) on the side of a mountain. The ibex strays from its herd in search of Indian lilac (nīm, Azadirachta indica, also known as nimtree) and black henna (katam, Buxus dioica), neither of which it finds. Instead, it comes across a hunter, who capitalizes on the animal's distance from the herd:

Hattā utīha lahū rāmin bi-muḥdalatin/

ja'shin wa-bīẹin nawāhīhinna ka l-sajamī ${ }^{47}$

Dallā yadayhi lahū qașran ${ }^{48}$ fa-alzamahū/

naffāḥatan ghayra ikhțāìn ${ }^{49}$ wa-lā sharamī

Fa-jāla minhu bi-a'lā l-raydi thumma kabā/

'alā naḍiyyin khilāla l-jawfín ${ }^{50}$ munhạtimī

Then fate decreed a shooter with a delicate, well-worn bow

and white arrows whose blades are like willow leaves. ${ }^{51}$

He hung his hands from above, to let fly with utmost power (qașran),

then dealt it a bloodspattering shaft, nor flying amiss

nor merely grazing skin.

The ibex fled the high mountain ridge, then fell forward

onto the bare bolt, which pierced its gut through to the ribs.

In these lines, later Arabic commentators saw the human-centered fatalism so familiar to pre-Islamic verse. Even the pre-Islamic and mukhadram poets themselves felt this way, a fact that can be discerned from the case of Abu Dhu'ayb, the pupil of Sāidah, who expanded his mentor's themes into the single most celebrated Hudhali poem: an elegy to his five sons who died of plague within a single year, and in which the tragic abruptness of their fate is likened to wild asses (jawn, "humpbacked," and jadāid, "plump [she-asses]") killed by a hunter's bow and arrow; a lone oryx (shabab) attacked by hounds; and two champion warriors (sing. kamiyy, pl. kumāt) who slay each other in battle (Jones 2011, pp. 493-524).

However, in al-Ma arrī's hands, the creatures killed by hunters become revivified subjects per se, with their poems as evidence of the harm that humans do. More than that, al-Ma'arrī often assumes that the harms described by poetry are real- "There is no doubt that this is still done even today" (wa-lā rayba annahu yuf alu ilā al-yawm) (Al-Ma'arrī 1975, p. 137). In this sense, he reverses the

46 Lines 8, 15, and 16 occupy the same order in both the Șāhil and al-Sukkarī. Lines 9, 10, 12, and 13 in the Șāhil are, respectively, lines 10,9, 14, and 12 in al-Sukkarī. Most of the variant recensions change by just a single word, e.g. al-Sukkārī's yanzuruhā versus al-Ma' arrī's yarqubuhā in line 11. The only major change appears in the first hemistich of al-Ma' arrī's line 10, yarūdu fīhā nahāran thumma mawriduhū / țāmin 'alayhi furū' u l-qāni wa-l-nashamī ("Here it wanders during the day, followed by its drinking/where branches of grewia and old man's beard [Clematis vitalba] drape overhead"), versus al-Sukkarī's line 9, ya'wī ilā mushmakhirrātin muṣa" idatin/shummin bi-hinna furü' u l-qāni wa-l-nashamī ("It takes shelter in points up high/where branches of grewia and old man's beard spread out overhead").

47 Al-Sukkarī $(1965$, vol. 3, p. 1126) and Al-Dīnawarī (1974, p. 305) both give al-saham.

48 Al-Sukkarī has sayran, "flying" (lit. "moving," "going") (Al-Sukkarī 1965, p. 134).

49 Al-Sukkarī has ghayra inbā'in, "without warning" (Al-Sukkarī 1965, p. 134).

50 Al-Sukkarī has khilāla l-ṣadri, "through the chest" (Al-Sukkarī 1965, p. 134).

51 Lane translates al-saham as "a kind of tree," but says of al-sajam that it refers to the leaves of a tree called khiläf and which-most relevant here-are often compared to arrowheads (Lane 1984, vol. 1, p. 1322). Most scholars translate khiläf as "Egyptian willow," Salix aegyptiaca, in Arabic șafșäf miṣrī (e.g., Stetkevych 2002, p. 112; Nasrallah 2017, p. 296; Dozy 1877-1881, vol. 1, p. 397), or simply "willow" (Al-Harīrī 2020, p. 285); while a minority give "oleaster," Elaeagnus angustifolia, known as Persian olive, or in French, chalef and eleagne (e.g., Fahd 1996, p. 826). Although the term khiläf might refer to both trees, this seems unlikely, since willows and oleasters belong not just to different biological genera, but in fact to different families, Salicaceae (the willow family) and Elaeagnaceae (the oleaster family) (ambiguity in Arabic animal terms tends to stay at the genus level, e.g. namir, which denotes the genus Panthera, hence why it is used interchangeably to mean "tiger," "leopard," or "panther," or ghuräb for the genus Corvus and which is used to mean "crow" or "raven"). 
customary place of animals in poetry. Jaroslav Stetkevych writes that the journeying poet's she-camel (nāqah), along with the oryx (shabab or mahā) or onager ('ayr or fara') to which it is often compared, assumes a legendary, unicorn-like quality, comparable to the curios of 'ajāib and nawādir literature, since all three creatures appear by epithet more than by name (Stetkevych 2002; Bauer 1992, vol. 1, pp. 35-38). One should not overstate the point about myth, since camels, oryx, and onagers still existed when the early 'Abbāsids wrote their commentaries, unlike the mythical geography of place names or topographical features common to pre-Islamic poetry. However, it is an intriguing conceptual foil al-Ma'arrī's approach, in which animals begin as symbols for human fate, only to wind up as real, pitiable beings.

In fact, not just poetry but also popular sayings (amthāl) become zoocentrized in the Șāhil. Sometimes they show up as proof of human cruelty, as for instance when the horse reproduces rajaz poetry "on urging [people] to eat spiny-tailed lizard [genus: Uromastyx]" (fĩ l-ḥathth 'alā akl al-ḍabb) (Al-Ma'arrī 1975, p. 150), since lizard gut fat is a proverbial Bedouin delicacy:

Aṭ im akhāka min 'aqanqali 1-ḍabb

innaka in lā tuṭ imanhu yaghḍab

Feed your brother lizard gut fat-

if you don't, then he'll get mad! ${ }^{52}$

Taken as a maxim, these lines mean, "be generous to others," but the horse turns them-ironically-into a reason to mistrust others. Other times, popular amthāl serve as plot points, like the expression "more deceptive than a dove" (akdhab min fākhitah), which comes up as the mule and horse debate whether to let the dove character, al-fākhitah, convey the mule's message (ibid., p. 211). Earlier in the story, the mule had also cited poetic description of horses as noble creatures, in order to flatter the horse character (al-șāhil) and prove its competence to carry a message to 'Azīz al-Dawlah' (ibid., pp. 156-57).

Most of the time, al-Ma'arrī is playful and keeps his eye on literary effects when he shifts the focus of poetry and amthāl to the animals themselves. However, if one assumes that he is being earnest, especially when he tries to prove animal agency, then he ignores another writer's advice from two hundred years earlier about equating allegory with reality. In the Kitāb al-Hayawān, al-Jāhị had urged readers to mark off proverbs referring to the natural faculties of animals, e.g., "stupider than a bustard" (ạ̣maq min ḥubārā), from proverbs that figuratively treat animals as if morally responsible, such as "more deceptive than a dove." Al-Jāhiz warns against interpreting the second type of proverb literally, thereby confusing human and animal status, since only humans have reason and thus moral agency (Miller 2017, pp. 105-7). Any claims to the contrary, reasons al-Jāhiz, look like the panpsychic beliefs of the aṣhāb al-jahālāt mentioned above.

The prospect of al-Ma'arrī taking things too literally, at least considering what others say about literary allegory, introduces a sweet irony. Here is a man who constantly resorts to non-literalism -allusions, riddles, double entendre, and obscure meanings for everyday words-to dupe readers into critical self-reflection. Granted, by zoocentrizing the Arabic written tradition, he offers an exceptional way to understand that tradition, even out of a Midas-like yearning to make everything he touches into a pacifist, vegan cautionary tale. Yet at the same time, this method tries to bend the meaning of certain texts to suit his needs, in a way that many commentators would not support. Furthermore, his approach equates literary discourse with historical reality, a tactic that al-Ma arrī dismisses out of hand whenever readers take his dubious statements at face value, or, as seen previously in Risālat al-ghufrān, when readers buy into overly literal visions of the afterlife. However, he seems more sanguine to do it himself, at least when it affirms God's justice for nonhuman beings.

52 Also found in (Tha' lab 1960, vol. 2, p. 506; Al-Ābī 1980-1991, vol. 6, p. 201; Al-Tawhīìi 1988, vol. 6, p. 162, quoting Ibn al-'Amīd; Al-Maydānī 1959, vol. 1, p. 431, no. 2271). Ironically, the uromastyx lizard appears again in the Șāhil—though only in passing_as "judge of all the animals" (qādī al-bahäim) (Al-Ma'arrī 1975, p. 214). 
These perplexing chinks in al-Ma'arrī's armor could be a sign of anthropocentrism masquerading as animal ethics. Perhaps, as with texts like Kalīla wa-Dimnah or the letters of the Ikhwān al-Ṣafā' nonhuman creatures stand for human behavior whether good or ill. However, from another viewpoint, the fact of self-contradiction speaks not to insincerity but instead to an active mind working through ethical quandaries. This point recalls the words of James Montgomery on al-Jāhiz, who, appearing at times to contradict himself, exhibits from another perspective a nimble intellect at work on the difficulties of large-scale thought: "As with other great systematizers such as Plato, Aristotle, St. Augustine or Montaigne, the integrity of the system is at its most vibrant when evidence of its development is most conspicuous" (Montgomery 2006, p. 21). Seen in this way, irreconcilable points about al-Ma arrī speak to his deeply held concern for animals, which no amount of literary equivocation or apparent anthropocentrism could keep hidden.

Funding: This research received no external funding.

Acknowledgments: Many thanks to Geert Jan van Gelder, Devin Stewart, Matthew Melvin-Koushki, Nathaniel Miller, Theodore Beers, Bella $\mathrm{Xu}$, and the anonymous reviewers for their thoughtful and generous feedback. Any errors are mine alone. Most of all, I am grateful to Sarra Tlili for betting on a greenhorn scholar, for her careful work on animals in Islam, and for her discerning editor's eye.

Conflicts of Interest: The author declares no conflict of interest.

\section{References}

Aḥmad, Muḥammad Shākir, and 'Abd al-Salām Hārūn, eds. 1955. Al-Aṣma iyyāt, 5th ed. Cairo: Dār al-Ma'ārif, Repr. in Beirut. 5th repr, n.d.

Al-Ābī, Abū Sa'd Manșūr ibn al-Ḥūsayn. 1980-1991. Nathr al-durr fì l-muhādarāat. Edited by Muhammad 'Alī Qarnah and 'Alī Muhammad al-Bijāwī. 7 vols. Cairo: Dār Al-Hay'ah al-Mișriyyah Al-Āmmah li-l-Kitāb.

Al-Akhfash, al-Așghar. 1999. Kitāb al-Ikhtiyārayn, al-Mufaḍ̂aliyyāt wa-l-Așmaiiyyāt. Edited by Fakhr al-Dīn Qabāwah. Damascus: Dār al-Fikr.

Al-Andalusī, Ibn Shuhayd. 1967. Risālat al-tawābi wa-l-zawābi . Edited by Buṭrus al-Bustānī. Beirut: Dār Ṣādir.

Al-Bațalyawsī, Ibn al-Sīd. 1991. Sharh al-Mukhtār min Luzūmiyyāt Ab̄̄ l-Alā'. Edited by Ḥāmid 'Abd al-Majīd. 2 vols in 1. Cairo: Al-Hay'ah al-Mișriyyah al-Āmmah li-l-Kitāb.

Al-Bațalyawsī, Ibn al-Sīd. 2008. Sharh al-ash'ầr al-Sittah al-Jāhiliyyah. Edited by Nāṣịf Sulaymān 'Awwād. 2 vols. Beirut: Al-Ma' had al-Almānī li-l-Abḥāth al-Sharqiyyah.

Al-Bīrūnī, Abū Rayhān. 2020. The Yogi Sutras of Patañjali. Edited by Mario Kozah. Translated by Mario Kozah. New York: Library of Arabic Literature; New York University Press.

Al-Bukhārī, Muhammad ibn Ismā̄ìl. 2002. Sahịh al-Bukhārī. Beirut and Damascus: Dār Ibn Kathīr.

Al-Dabbī, Al-Mufaḍal ibn Muhammad. 1921. The Mufaddalīyāt: An Anthology of Ancient Arabian Odes. Edited by Charles James Lyall. Translated by Charles James Lyall. 2 vols. Oxford: Clarendon Press.

Al-Dīnawarī, Abū Hanīfah. 1974. Kitāb al-nabāt. Edited by Bernhard Lewin. Wiesbaden: Franz Steiner Verlag GMBH.

Al-Ḥarīrī, Abū Muhammad al-Qāsim. 2020. Impostures. Translated by Michael Cooperson. New York: Library of Arabic Literature; New York University Press.

Al-Jāhịiz, Abū 'Uthmān 'Amr ibn Baḥr al-Kinānī. 1938. Kitāb al-hayawān, 2nd ed. 1965-1969. Edited by 'Abd al-Salām Muḥammad Hārūn. 8 vols. Cairo: Sharikat Maktabat wa-Maṭba at Muṣtafā al-Bābī al-Ḥalabī wa-Awlādihi.

Al-Jāhịiz, Abū 'Uthmān 'Amr ibn Baḥr al-Kinānī. 1948. Kitāb al-bukhalā. Edited by Tāhā al-Hajirī. Cairo: Dār al-Ma'ārif.

Al-Jāhịiz, Abū 'Uthmān 'Amr ibn Baḥr al-Kinānī. 1997. The Book of Misers: A Translation of al-Bukhalā. Translated by Robert Bertram Serjeant. Reading: Garnet.

Al-Jundī, Muhammad Salīm, ed. 1962-1964. Al-Jāmi fì akhbār Ab̄̄ l-Alà al-Máarrī wa-āthārihi. 3 vols. Damascus and Beirut: Dār Ṣādir, Repr. 1992.

Al-Kalā'ì, Abū l-Qāsim Muhammad ibn 'Abd al-Ghafūr. 1985. Inkām ṣan'at al-kalām, fí funūn al-nathr wa-madhāhibihi fì l-mashriq wa-l-Andalus, 2nd repr. Edited by Muhammad Rị̣wān al-Dāyah. Beirut: 'Ālam al-Kutub.

Al-Ma'arrī, Abū l-Alā'. 1891-1895. Luzūm mā lā yalzam. Edited by 'Azīz Zand. 2 vols. Cairo: Maṭba' at al-Mahrūsah. 
Al-Ma arrī, Abū l-Alā'. 1938. Al-Fuṣūl wa-l-Ghāyāt fì Tamjīd Allāh wa-l-Mawāi iz. Edited by Mahmūd Hasan Zanātī. Cairo: Mațba' at Hijāzī.

Al-Ma arrī, Abū l-'Alā'. 1945. Shurūh Saqt al-zand, 3rd ed. Edited by Tāhā Husayn, Muștāfā al-Saqā, 'Abd al-Salām Hārūn, 'Abd al-Raḥ̄m Maḥmūd, Ibrāhīm al-Ibyārī and Hāmid 'Abd al-Majīd. 5 vols. Cairo: Dār al-Kutub al-Missriyyah. 3rd repr. 1986, Repr. 1965.

Al-Ma arrī, Abū l-'Alā'. 1975. Risālat al-șāhil wa-l-shāhij. Edited by 'Āishah 'Abd al-Rahmān Bint al-Shātí'. Cairo: Dār al-Ma'ārif, Repr. 1984.

Al-Ma'arrī, Abū l-'Alā'. 1982. Rasāil Ab̄̄ l-'Alā al-Ma'ārrī: al-juz al-awwal. Edited by Ihsān 'Abbās. Beirut: Dār al-Shurūq.

Al-Ma'arrī, Abū l-'Alā'. 2013-2014. The Epistle of Forgiveness. Edited by Gregor Schoeler and Geert Jan van Gelder. Translated by Gregor Schoeler, and Geert Jan van Gelder. 2 vols. New York: Library of Arabic Literature; New York University Press.

Al-Maydān̄ì, Abū l-Fadl Aḥmad ibn Muḥammad. 1959. Majma' al-amthāl. Edited by Muhammad Muhyī l-Dīn 'Abd al-Hamīd. 2 vols. Cairo: Al-Maktabah al-Tijāriyyah.

Al-Nīsābūrī, Abū l-Hasan Muslim ibn al-Hajjāj. 1991. Șaḥ̂ḥ Muslim. Edited by Muhammad Fu'ād 'Abd al-Bāqī. 5 vols. Beirut: Dār Ihyā' al-Kutub al-'Arabiyyah.

Al-Qifṭī, Jamāl al-Dīn Abū l-Hasan ibn Yūsuf. 1950. Inbāh al-ruwāàt 'alā anbāà al-nuḥāt. Edited by Muhammad Abū 1-Fadl Ibrāhīm. 4 vols. Cairo: Dār al-Kutub al-Miṣriyyah.

Al-Shāfi ì, Muhammad ibn Idrīs. 2001. Kitāb al-umm. Edited by Rif at Fawzī 'Abd al-Muttalib. 11 vols. Mansoura, Egypt: Dār al-Wafā'.

Al-Shirbīnī, Yūsuf. 2016. Brains Confounded by the Ode of Abū Shādūf Expounded. Edited by Humphrey Davies. Translated by Humphrey Davies. New York: Library of Arabic Literature; New York University Press.

Al-Sukkarī, Abū Sa'ìd al-Hasan ibn al-Husayn. 1965. Sharh ash'ār al-Hudhaliyyīn. Edited by 'Abd al-Sattār Aḥmad Farrāj and Mahmūd Muhammad Shākir. 3 vols. Cairo: Maṭba' at al-Madanī, Repr. 1995.

Al-Sulamī, 'Izz al-Dīn 'Abd al-'Azīz ibn 'Abd al-Salām. 1991. Qawā̄id al-aḥkām fì maṣālih al-anām. Edited by Tāhā 'Abd al-Ra'ūf Sa'd. 2 vols. Cairo: Maktabat al-Kulliyyāt al-Azhariyyah.

Al-Sulamī, 'Izz al-Dīn 'Abd al-'Azīz ibn 'Abd al-Salām. 2010. Rules of the Derivation of Laws for Reforming the People (Qawa'id al-Ahkam fi Islah al-Anam). English translation. Kuala Lumpur: Islamic Banking and Finance Institute Malaysia (IBFIM).

Al-Tawhīīī, Abū Hayyān. 1988. Al-Bașāir wa-l-dhakhāir. Edited by Wadād al-Qādī. 10 vols. in 6. Beirut: Dār Ṣādir. Amanat, Abbas. 1996. The Nuqțawī Movement of Maḥmūd Pisīkhānī and his Persian Cycle of Mystical-Materialism. In Medieval Isma ili History and Thought. Edited by Farhad Daftary. Cambridge: Cambridge University Press, pp. 281-97.

Antoon, Sinan. 2011. Abū '-'Alā' al-Ma'arrī. In Essays in Arabic Literary Biography, Volume 2: 925-1350. Edited by Terri DeYoung and Mary St. Germain. Wiesbaden: Harrassowitz Verlag, pp. 228-34.

Arthur John Arberry, trans. 1955, The Koran Interpreted, 3rd ed. 2 vols in 1. Toronto: George Allen \& Unwin Ltd., Repr. 1969.

'Aț̣āar, Farīd al-Dīn. 1905-1907. The Tadhkiratu'l-Awliyá ("Memoirs of the Saints") of Muhammad ibn Ibráhím Farídu'ddín 'Atțár. Edited by Reynold A. Nicholson. 2 vols. London: Luzac \& Co., Leiden: E.J. Brill.

'Atṭār, Farīd al-Dīn. 1966. Muslim Saints and Mystics: Episodes from the Tadhkiratal-Auliya' (Memorial of the Saints). Translated by Arthur John Arberry. London and New York: Routledge, Online 2008.

Augustine. 1957. City of God, Volume 1: Books 1-3. Translated by George E. McCracken. Cambridge: Harvard University Press.

Babayan, Kathryn. 2002. Mystics, Monarchs, and Messiahs: Cultural Landscapes of Early Modern Iran. Cambridge and London: Harvard University Press.

Barkoudah-Raoux, Joumana. 2009. Al-Ma'arri, ou l'Art D'écrire sous la Censure: l'exemple de Risalat al-sahil wa-1 shahig, "L'Épître du Cheval et du mulet". Ph.D. dissertation, Université Lumière Lyon, Lyon, France.

Bauer, Thomas. 1992. Altarabische Dichtkunst: Eine Untersuchung ihrer Struktur und Entwicklung am Beispiel der Onagerepisode. 2 vols. Wiesbaden: Harrassowitz Verlag.

Black, Deborah L. 1993. Estimation (Wahm) in Avicenna: The Logical and Psychological Dimensions. Dialogue XXXII: 219-58. [CrossRef]

Blankinship, Kevin. 2019a. Al-Ma'arrī's Esteem in the Islamic West: A Preliminary Overview. Al-Masāq: Journal of the Medieval Mediterranean 31: 253-71. [CrossRef] 
Blankinship, Kevin. 2019b. Missionary and Heretic: Debating Veganism in the Medieval Islamic World. In Insatiable Appetite: Food as Cultural Signifier in the Middle East and Beyond. Edited by Kirill Dmitriev, Julia Hauser and Bilal Orfali. Leiden: Brill, pp. 260-91.

Burge, Stephen Russell. 2009. Angels in Islam: A Commentary with Selected Translations of Jalāl al-Dīn al-Suyūtī's Al-Habāik fī akhbār al-malāik (The Arrangement of the Traditions about Angels). Ph.D. dissertation, The University of Edinburgh, Edinburgh, UK.

Chittick, William. 2020. Spring 2020 online edition. Ibn 'Arabî. In The Stanford Encyclopedia of Philosophy. Edited by Edward N. Zalta. Stanford: Stanford University Press, Available online: https://plato.stanford.edu/archives/ spr2020/entries/ibn-arabi/ (accessed on 5 May 2020).

Crone, Patricia. 2012a. Al-Jāhịiz on Aṣhāb al-Jahālāt and the Jahmiyya. In Medieval Arabic Thought: Essays in Honour of Fritz Zimmermann. Edited by Rotraud Hansberger, Muhammad Afifi al-Akiti and Charles Burnett. London and Turin: The Warburg Institute and Nino Aragno Editore, pp. 27-39.

Crone, Patricia. 2012b. The Nativist Prophets of Early Islamic Iran: Rural Revolt and Local Zoroastrianism. Cambridge: Cambridge University Press.

Dozy, Reinhart. 1877-1881. Supplément aux Dictionnaires Arabes. 2 vols. Leiden: E.J. Brill, EI2 = Encyclopedia of Islam, Second Edition. 1960 (vol. 1)-2009 (index vol.); 2012 online. Leiden: Brill Online.

Fahd, Toufic. 1996. Botany and Agriculture. In Encyclopedia of the History of Arabic Science. Edited by Rashed Roshdi and Régis Morelon. London: Routledge, pp. 813-52.

Furber, Musa. 2015. Rights and Duties Pertaining to Kept Animals: A Case Study in Islamic Law and Ethics. Abu Dhabi: Tabah Foundation.

Glick, Thomas F. 1979. Islamic and Christian Spain in the Early Middle Ages. Princeton: Princeton University Press.

Goffman, Erving. 1981. Forms of Talk. Philadelphia: University of Pennsylvania Press.

Lenn E. Goodman, and Richard McGregor, transs. 2009, The Case of the Animals versus Man before the King of the Jinn: A Translation from the Epistles of the Brethren of Purity. Oxford and New York: Oxford University Press, in association with the Institute of Ismaili Studies.

Gruber, Christiane. 2018. The Praiseworthy One: The Prophet Muhammad in Islamic Texts and Images. Bloomington: Indiana University Press.

Heller-Roazen, Daniel, ed. 2010. The Arabian Nights. Based on the Edition of Muhsin Mahdi and Translation of Husain Haddawy. New York and London: W.W. Norton and Company.

Husayn, Tāhā, Muṣṭāfā al-Saqā, 'Abd al-Salām Hārūn, 'Abd al-Rahīm Mahmūd, Ibrāhīm al-Ibyārī, and Hāmid 'Abd al-Maj̄̄d, eds. 1944. Tá rīf al-qudamā bi-Abī l-'Alā. Cairo: Wizārat al-Ma'ārif al-'Umūmiyyah.

Ibn al-Kalb̄̄, Abū l-Mundhir Hishām. 1995. Kitāb al-aṣnām, 3rd repr. Edited by Aḥmad Zakī Bāshā. Cairo: Dār al-Kutub al-Mișriyyah.

Ibn Durayd, al-Azdī. 1987-1988. Jamharat al-lughah. Edited by Ramzī Ba'labakkī. 3 vols. Beirut: Dār al-'Ilm li-l-Malāyīn.

Ibn Manẓūr. 1999. Lisān al-'arab, 3rd repr. Edited by Amīn Muhammad 'Abd al-Wahhāb and Muhammad Ṣādiq al-'Ubaydī. 17 vols. Beirut: Dār Ihyā' al-Turāth al-'Arabī.

Ibn Qutaybah, Abū Muhammad 'Abd Allāh. 1953. Kitāb al-ma'ān̄̄al-kabīr. Edited by Fritz Krenkow. 7 vols. Beirut: Dār al-Nahḍah al-Hadīthah.

Ibn Qutaybah, Abū Muhammad 'Abd Allāh. 1996. 'Uyūn al-akhbār. 2nd repr. 4 vols. Cairo: Dār al-Kutub al-Mișriyyah.

Ibn Ṭufayl. 2008. Hayy ibn Yaqzān l-Ibn Sīnā wa-Ibn Ṭufayl wa-l-Suhrawardī, 4th repr. Edited by Aḥmad Amīn. Cairo: Dār al-Ma'ārif.

Tufayl, Ibn. 2009. Ibn Tufayl's Hayy ibn Yaqzan: A Philosophical Tale, 6th ed. Translated by Lenn Evan Goodman. Chicago: University of Chicago Press.

Ikhwān, al-Ṣafā'. 1957. Rasāil Ikhwān al-Ṣafā wa-khullān al-wafā'. Foreword by Buṭus al-Bustānī. 4 vols. Beirut: Dār Șādir, Qom: Maktab al-Il'ām al-Islāmī, Repr. 1985.

Alan Jones, trans. 2011, Early Arabic Poetry: Select Poems, 2nd ed. Reading: Ithaca Press.

Komnene, Anna. 1969. The Alexiad. Translated by Robert Sewter. London: Penguin Books, Repr. 2003; rev. ed. 2009.

Kurd 'Alī, Muhammad, ed. 1913. Rasāil al-bulaghā'. 2 parts in 1. Cairo: Dār al-Kutub al-'Arabiyyah al-Kubrā.

Lagerlund, Henrik. 2018. Food Ethics in the Middle Ages. In The Oxford Handbook of Food Ethics. Edited by Anne Barnhill, Mark Budolfson and Tyler Doggett. Oxford: Oxford University Press, pp. 759-72. 
Lane, Edward William. 1984. Arabic-English Lexicon. 8 vols. in 2. Cambridge: Islamic Texts Society.

Mahdi, Muhsin. 1984-1994. The Thousand and One Nights (Alf Layla wa Layla): From the Earliest Known Sources. 3 vols. Leiden: Brill.

Margoliouth, David S. 1902. Abu'l-Alā al-Ma'arrī's Correspondence on Vegetarianism. Journal of the Royal Asiatic Society of Great Britain and Ireland April: 289-332. [CrossRef]

Melvin-Koushki, Matthew. Forthcoming. The New Brethren of Purity: Ibn Turka and the Renaissance of Neopythagoreanism in the Early Modern Persian Cosmopolis. In Companion to the Reception of Pythagoras and Pythagoreanism. Edited by Robert Aurélien, Irene Caiazzo and Constantin Macris. 2 vols. Leiden: Brill.

Miller, Nathaniel. 2016. Tribal Poetics in Early Arabic Culture: The Case of Ash'ār al-Hudhaliyyīn. Ph.D. dissertation, The University of Chicago, Chicago, IL, USA.

Miller, Jeannie. 2017. Man is Not the Only Speaking Animal: Thresholds and Idiom in al-Jāhiz. In Arabic Humanities, Islamic Thought: Essays in Honor of Everett K. Rowson. Edited by Joseph E. Lowry and Shawkat M. Toorawa. Leiden and Boston: Brill, pp. 94-121.

Moin, A. Azfar. 2012. The Millennial Sovereign: Sacred Kinship E Sainthood in Islam. South Asia Across the Disciplines. New York: Columbia University Press.

Montgomery, James. 2006. Beeston and the Singing-Girls. Proceedings of the Seminar for Arabian Studies 36: 17-24.

Nasrallah, Nawal, ed. 2017. Treasure Trove of Benefits and Variety at the Table: A Fourteenth-Century Egyptian Cookbook. Leiden: Brill.

Nutton, Vivian. 1984. From Galen to Alexander: Aspects of Medicine and Medical Practice in Late Antiquity. Dumbarton Oaks Papers 38: 1-14. [CrossRef]

Obolensky, Daniel. 1948. The Bogomils: A Study in Balkan Neo-Manichaeism. Cambridge: Cambridge University Press, Twickenham: Anthony C. Hall, Repr. 1972.

Plutarch. 1927-2004. Moralia. Translated by Harold Cherniss, William Clark Hembold, Paul Augustus Clement, Herbert Benno Hoffleit, Frank Cole Babbitt, Philip Howard de Lacy, Benedict Einarson, Lionel Pearson, Francis Henry Sandbach, Harold North Fowler, and et al.. 16 vols. Loeb Classical Library. Cambridge: Harvard University Press.

Sahl, ibn Hārūn. 1973. Kitāb al-namir wa-l-tha' lab. Edited by 'Abd al-Qādir Mahīrī. Tunis: Al-Jām iyah al-Tunisiyyah, Kulliyyat al-Ādāb wa-l-'Ulūm al-Insāniyyah.

Sezgin, Fuat. 1974-1995. Geschichte des arabischen Schriftums. vols. 1-9, plus index vol.; 2000-2005, vols. 10-12. Leiden: Brill, (vols. 1-9). Frankfurt am Main: Institute for the History of Arabic-Islamic Science, (vols. 10-12).

Sheibani, Mariam. 2020. Innovation, Influence, and Borrowing in Mamluk-Era Legal Maxim Collections: The Case of Ibn 'Abd al-Salām and al-Qarāfī. Journal of the American Oriental Society. Forthcoming.

Smoor, Pieter. 1981. Enigmatic Allusion and Double Meaning in Ma'arrī's Newly-Discovered 'Letter of a Horse and a Mule'. Part 1. Journal of Arabic Literature 12: 49-73. [CrossRef]

Smoor, Pieter. 1982. Enigmatic Allusion and Double Meaning in Ma'arrī's Newly-Discovered 'Letter of a Horse and a Mule'. Part 2. Journal of Arabic Literature 13: 23-52. [CrossRef]

Stetkevych, Jaroslav. 2002. In Search of the Unicorn: The Onager and the Oryx in the Arabic Ode. Journal of Arabic Literature 33: 79-130. [CrossRef]

Stoneman, Richard. 2020. The Greek Experience of India: From Alexander to the Indo-Greeks. Princeton: Princeton University Press.

Strauss, Leo. 1941. Persecution and the Art of Writing. Social Research 8: 488-504.

Tha'lab, Abū l-'Abbās Aḥmad ibn Yahyā. 1960. Majālis Tha'lab. Edited by 'Abd al-Salām Muhammad Hārūn. 2 vols. Cairo: Dār al-Ma'ārif, 1st repr.

Tlili, Sarra. 2010. The Meaning of the Quranic Word 'dābba': 'Animals' or 'Nonhuman Animals'? Journal of Quranic Studies 12: 167-87.

Tlili, Sarra. 2012. Animals in the Qur'an. Cambridge: Cambridge University Press.

Tlili, Sarra. 2014. All Animals are Equal, or Are They? The Ikhwān al-Ṣafā's Animal Epistle and its Unhappy End. Journal of Qur'anic Studies 16: 42-88.

Tlili, Sarra. 2015. Animals Would Follow Shāfi ism: Legitimate and Illegitimate Violence to Animals in Medieval Islamic Thought. In Violence in Islamic Thought from the Qur'an to the Mongols. Edited by Robert Gleave and István T. Kristó-Nagy. Edinburgh: Edinburgh University Press, pp. 225-44. 
Tlili, Sarra. 2017. From Breath to Soul: The Quranic Word Rūh and Its (Mis)Interpretations. In Arabic Humanities, Islamic Thought: Essays in Honor of Everett K. Rowson. Edited by Joseph E. Lowry and Shawkat M. Toorawa. Leiden and Boston: Brill, pp. 1-21.

Ullmann, Manfr. 1981. Das Gespräch Mit Dem Wolf: Beiträge zur Lexikographie des Klassischen Arabisch. Munich: Verlag der Bayerischen Akademie der Wissenschaften, in Kommission bei C.H. Beck.

Walker, Paul. 1991. The Doctrine of Metempsychosis in Islam. In Islamic Studies Presented to Charles J. Adams. Edited by Wael B. Hallaq and Donald P. Little. Leiden, New York, Copenhagen and Cologne: E.J. Brill, pp. 219-38.

Weiss, Bernard G. 1998. The Spirit of Islamic Law. Athens and London: The University of Georgia Press.

Timothy John Winter, trans. 1995, Al-Ghazālī: On Disciplining the Soul (Kitāb riyādat al-nafs) \& On Breaking the Two Desires (Kitāb kasr al-shahwatayn), Books XXII and XXIII of the Revival of the Religious Sciences (Ihȳà 'ulüm al-dīn). Cambridge: Islamic Texts Society.

(C) 2020 by the author. Licensee MDPI, Basel, Switzerland. This article is an open access article distributed under the terms and conditions of the Creative Commons Attribution (CC BY) license (http://creativecommons.org/licenses/by/4.0/). 